\title{
Spore exposure arising from stored hay, grain and straw
}

\author{
MARJUT KOTIMAA \\ Kuopio Regional Institute of Occupational Health, P.O.B. 93, \\ SF-70701 Kuopio, Finland
}

\begin{abstract}
The quantitative and qualitative differences in microbe exposure arising from hay, grain and straw during the end of the indoor feeding period were investigated by using a six-stage fractionating impactor (model 10-800, Andersen Inc.). Straw samples $(\mathrm{n}=5)$ liberated significantly higher amounts of spores $\left(3.7 \times 10^{6} \mathrm{cfu} / \mathrm{m}^{3}\right.$ air $)$ in comparison to hay samples $(\mathrm{n}=33)$ and grain samples $(\mathrm{n}=2)$, which liberated $0.6 \times 10^{6} \mathrm{cfu} / \mathrm{m}^{3}$ and $0.2 \times 10^{6} \mathrm{cfu} / \mathrm{m}^{3}$, respectively. Thermotolerant and thermophilic microflora were typical of the exposure originating from straw. Hay liberated about $10 \%$ and grain only $0.7 \%$, the level of spores of thermotolerant fungi liberated from straw. The corresponding percentages of spores of thermophilic actinomycetes were $5 \%$ and $0.4 \%$. Thermoactinomyces vulgaris was the dominating microbe in the exposure caused by straw; Aspergillus umbrosus was the major species in the microflora liberated from hay and grain. Other Aspergillus (A.) species (A. fumigatus, A. ochraceus, $A$. flavus, A. repens, A. versicolor) and Penicillium (P.) species ( $P$. expansum, $P$. piceum, $P$. citrinum, $P$. brevicompactum, $P$. echinulatum, $P$. verrucosum var. cyclopium) occurred frequently, and in great amounts, in all the analysed materials. Spores of Cladosporium (C.) species (mainly $C$. herbarum, C. cladosporioides, and C. macrocarpum) were found frequently, and abundantly, during the handling of hay. The present results suggest that not only the traditional causative agènts of farmer's lung disease but also other fungal and actinomycete species may be found in hight concentrations during the handling of bedding and feeding stuffs, and that these fungal and actinomycete exposures may cause respiratory symptoms and other health problems in both man and animals. Special attention should be paid to decreasing the moisture content of hay and straw before storing in order to lower the risk of moulding during the indoor feeding period.
\end{abstract}

\section{Introduction}

Dust problems are typical of agricultural working environments. Dust exposure consists mostly of organic particles, which originate from feeding and bedding stuffs and from animals and their excrements. Organic components may include, e.g. animal dander, hair, feathers, manure, insects, mites, pollen, fungal spores or fragments of fungal hypha, bacteria and their endotoxins, mycotoxins and fodder particles. The amount and the quality of dust are affected by the branch of production, geographical location and the climatic conditions, and these factors are also related to the prevalence and the incidence of farm- 
er's lung (Terho et al. 1987, Vohlonen et al. 1987). Farmer's lung disease is one type of allergic alveolitis caused by fungal and actinomycete spores arising from mouldy plant material (PEPYs 1969).

The yearly incidence of allergic alveolitis in Finland has increased steadily from 101 cases in 1984 to 340 cases in 1988 . The vast majority of the cases occurs among farmers (VAARANEN et al. 1985, 1986, 1987, 1988, 1989), especially on dairy farms. Disease similar to farmer's lung has also been reported in bovines and in horses (PIRIE et al. 1971, WISEMAN et al. 1973, AsMUNDSSON et al. 1983). Hay has been accused of causing the disease, although other stored plant materials (feeding and bedding stuffs) used on farms are as susceptible to moulding as hay. The aim of the present study was to investigate quantitative and qualitative differences in microbe exposure arising from hay, grain and straw during the end of the indoor feeding period.

\section{Material and methods}

Material samples for aerobiological studies were taken at the end of indoor feeding period (in April and May) on the farms, which situated in Eastern Finland. Thirtythree farms were included in the study and hay samples were taken from baled hay, grain samples from grain which had been dried with unheated forced air and straw samples from baled straw. All the material samples represented average quality, exceptionally mouldy or good quality batches were excluded.

A six-stage fractionating impactor (model 10-800, Andersen Inc., Georgia, USA) was used to take air samples for analysing the quality and the quantity of viable microflora (ANDERSEn 1958). Samples were taken during the handling of hay $(\mathrm{N}=33)$, grain $(\mathrm{N}=2)$ and straw $(\mathrm{N}=5)$, at a distance of half a metre from the farmer's breathing zone.

Each sample included four successive measurements. Two sets of Hagen-medium (malt extract-glucose-agar (RUSSEL 1974) supplemented by $35 \mathrm{mg}$ streptomycin and $35 \mathrm{mg}$ Rose Bengal and diluted to $1000 \mathrm{ml}$ medium) were used. One sample was incubated at $20^{\circ} \mathrm{C}$ for the outgrowth of mesophilic fungi and the other was incubated at $40{ }^{\circ} \mathrm{C}$ to obtain colonies of thermotolerant fungi. NaCl-malt extract agar (Terho 1978) (incubation at $20^{\circ} \mathrm{C}$ ) was used for Aspergillus (A.) glaucus group fungi, and half-strength Nutrient agar (CORBAZ et al. 1963) (incubation at $55^{\circ} \mathrm{C}$ ) for thermophilic actinomycetes. After incubation, the colonies were identified using a lightmicroscope and counted. The positive hole correction method of ANDERSEN (1958) was used to count colonies before calculating the concentrations, which are expressed as colony-forming units per cubic metre of air $\left(\mathrm{cfu} / \mathrm{m}^{3}\right)$. The sampling time per medium varied from 5 to 30 seconds, according to the visible mouldiness of the material. In evaluating the differences in spore concentrations, one-way analysis of variance was used after the logarithmic transformation of calculated values. The Chi square test was applied to evaluate the differences in the frequencies of various microbes.

\section{Results}

Handling of feeding and bedding stuffs caused a high level of exposure, from $10^{4}$ to $10^{7} \mathrm{cfu} / \mathrm{m}^{3}$. Both the lowest and the highest total spore value was measured during the handling of hay $\left(19000 \mathrm{cfu} / \mathrm{m}^{3}\right.$ and $13700000 \mathrm{cfu} / \mathrm{m}^{3}$, respectively) (Table 1). In all cases, straw liberated large amounts of spores, the difference between straw and other materials being statistically significant $(\mathrm{F}=3.40, \mathrm{p}<0.05)$. Compared to hay and straw, grain samples caused only slight exposure to spores. Thermotolerant and thermophilic microflora were typical of the exposure originating from straw. Hay liberated about $10 \%$ and grain only $0.7 \%$, the level of spores of thermotolerant fungi liberated from straw. The corresponding percentages of 
Table 1. The concentration of airborne spores of different microbe groups expressed as geometric means (x) of colony forming units per $\mathrm{m}^{3}$ during the handling of various materials on farms.

\begin{tabular}{lccc}
\hline Microbe group & \multicolumn{3}{c}{ Material } \\
\cline { 2 - 4 } & Hay $\times 10^{3}$ & Straw $\times 10^{3}$ & Grain $\times 10^{3}$ \\
\hline Mesophilic fungi & 380 & 1900 & 160 \\
range & $(9.7-6600)$ & $(520-6500)$ & $(38-650)$ \\
Thermotolerant fungi & 24 & 230 & 1.6 \\
range & $(0.05-2000)$ & $(12-2600)$ & $(0.25-11)$ \\
Thermophilic actinomycetes & 36 & 670 & 1.6 \\
range & $(0.07-5100)$ & $(100-3300)$ & $(0.39-11)$ \\
Total & 630 & 3700 & 160 \\
range & $(19-14000)$ & $(2100-12000)$ & $(38-670)$ \\
\hline
\end{tabular}

spores of thermophilic actinomycetes were $5 \%$ and $0.4 \%(\mathrm{~F}=3.79, \mathrm{p}<0.05)$. Thermoactinomyces vulgaris was the dominating microbe in the exposure caused by straw $(\mathrm{F}=3.61, \mathrm{p}<0.001) ;$ Aspergillus umbrosus was the major species in the microflora liberated from hay and grain (Table 2). Other Aspergillus species (A. fumigatus, $A$. ochraceus, $A$. flavus, $A$. repens, $A$. versicolor) and Penicillium species ( $P$. expansum, $P$. piceum, $P$. citrinum, $P$. brevicompactum, $P$. echinulatum, $P$. verrucosum var. cyclopium) occurred frequently and in great amounts in all the analysed materials. Of the fungi that were found occasionally, or in minor concentrations, Humicola sp. was significantly more common in straw than in hay or grain $(\mathrm{F}=$ 3.93, $\mathrm{p}<0.05, \mathrm{X}^{2}=4.75, \mathrm{p}<0.10$ ) (Table 2). The spores of the Cladosporium species (mainly C. herbarum, C. cladosporioides and C. macrocarpum) were found frequently, and abundantly, during the handling of hay $(\mathrm{F}=$ $\left.4.35, \mathrm{p}<0.05, \mathrm{X}^{2}=6.12, \mathrm{p}<0.05\right)$.

\section{Discussion}

Each year, most cases of farmer's lung are diagnosed during the end of the indoor feeding period (Terho et al. 1980, Pether \& Greatorex 1976). During that time the exposure to airborne spores is greater than at the beginning of the indoor feeding period and small-spored storage fungi are mainly encoun- tered (KotimaA et al. 1978, 1981). A similar incidence pattern has also been reported among bovines, which contract respiratory disorders after having been fed mouldy hay (PIRIE et al. 1971, Wiseman et al. 1973). All samples were collected for this study during the season involving the highest exposure to spores, though there were noticeable differences in the quality and the quantity of exposure to spores during the handling of different materials.

Straw bedding caused the highest spore concentrations when compared to hay or grain; parallel results have also been published in other reports (Mulinge \& Chester 1970, LACEY 1971). The role of straw as a factor increasing exposure to spores on farms has not recieved much attention so far. The great numbers of thermotolerant fungi and thermophilic actinomycetes indicate spontaneous heating resulting from the high moisture content of stored material (FESTENSTEIN et al. 1965). Straw is collected, often by baling, when the weather is often rainy, or at least when the difference in temperature between the daytime and the night-time is great, and thus dew may provide sufficient moisture to initiate moulding. It has not been studied how straw could be collected and preserved without giving rise to conditions favourable to moulding. The quality of the microbe exposure originating from straw was much the same as that originating from hay and causing 


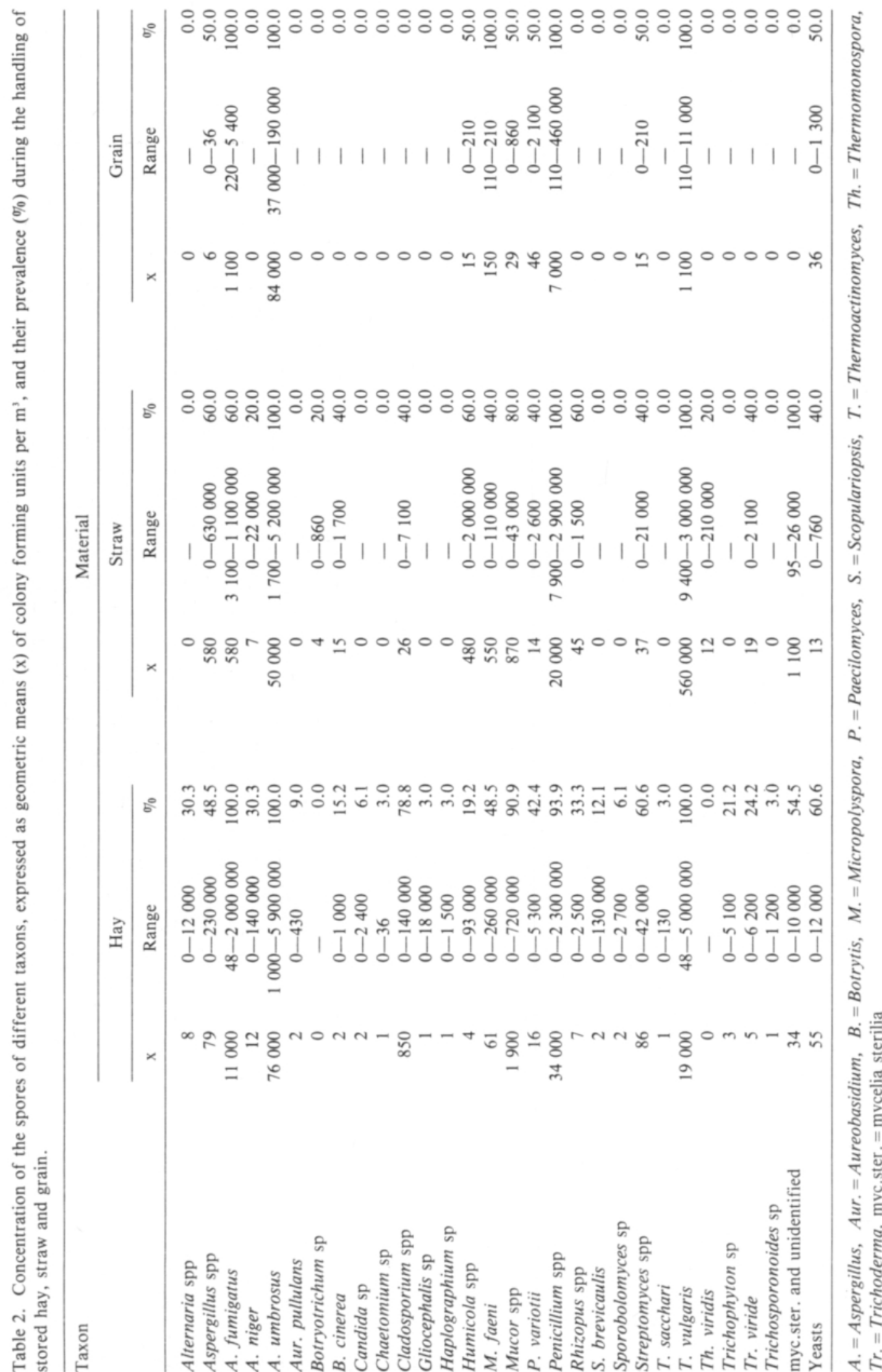


farmer's lung, as described by GREGORY \& LACEY (1963).

The hay samples in this study included both good quality and extensively moldy batches, which indicates great variation in the microbiological quality of baled hay on different farms. The presence of Cladosporium and $\mathrm{Al}$ ternaria species, however, indicates that the storage of hay probably promotes less microbiological deterioration than the storage of straw. If weather conditions during haymaking are unfavourable, the high moisture content of the hay allows the development of abundant thermotolerant and thermophilic microflora, e.g. A. fumigatus, T. vulgaris and $M$. faeni. The last-mentioned species requires a fairly high moisture content $(47 \%)$ of the material to grow (CROss et al. 1968). Such a high moisture content is rare in the climatic conditions of Finland, which may explain the rare occurrence of $M$. faeni in Finnish hay samples (KotimaA et al. 1983, Mustonen et al. 1984). However, if hay is baled, the moisture content of hay is more critical as to moulding, because less water evaporates from tightly baled hay than from loosely collected hay.

Evidently, the grain material of this study was of good microbiological quality, although the samples were dried by forced unheated air. The level of exposure has been found to be higher during the handling of cool-air-dried grain compared to the handling of grain preserved and stored with other methods, e.g. drying with heated forced air (MUSTONEN et al. 1983). Our results imply that, at least in dry threshing season, cool air drying may be effective enough to prevent moulding of grain. There were only few thermophilic Streptomyces species, which are characteristic of self-heated grain (FESTENSTEIN et al. 1965). Species that occurred frequently, and in great amounts, in all the investigated materials were the fungi of the genera Aspergillus, Penicillium and Mucor, and thermophilic actinomycetes from the genus Streptomyces (especially in hay and straw) and T. vulgaris.

The diagnosis of farmer's lung disease is based on symptoms, radiographic findings, lung function tests and the presence of microbial antibodies in serum (RYLANDER 1985). An antigen panel of four microbes (A. umbrosus, A. fumigatus, $T$. vulgaris and $M$. faeni) is used in serological tests for suspected cases of allergic alveolitis in Finland (TERHO 1978, Husman et al. 1987). The present results show that different species of Penicillium, Aspergillus, Mucor, and Streptomyces are at least as important as the above-mentioned species in the exposure occurring in agricultural working environments. It has been assumed that thermophilic actinomycetes would be more potent in causing allergic alveolitis than other microbes involved in moulding (W been cases of allergic alveolitis where the aetiological agents have been mesophilic fungi (Terho \& Lacey 1979), e.g. spores of Penicillium (Fergusson et al. 1984, Solley \& HyatT 1980). Thus any kind of moulding causing high concentrations of airborne spores should be considered an undesirable phenomenon.

\section{References}

Andersen, A.A. 1958. New sampler for the collection, sizing and enumeration of viable airborne particles. J. Bacteriol. 76: 471-484.

Asmundsson, T., Gunnarsson, E. \& Johannesson, T. 1983. "Haysickness" in Icelandic horses: Precipitin tests and other studies. Equine Vet. J. 15: 229-232.
Cross, T., Maciver, A.M. \& Lacey, J. 1968. The thermophilic actinomycetes in mouldy hay: Micropolyspora faeni sp.nov. J. Gen. Microbiol. 50: 351-359.

Corbaz, R., Gregory, P.H. \& Lacey, M.E. 1963. Thermophilic and mesophilic actinomycetes in mouldy hay. J. Gen. Microbiol. 32: 449-455. 
Fergusson, R.J., Milne, L.J.R., \& Crompton, G.K. 1984. Penicillium allergic alveolitis: Faulty installation of central heating. Thorax 39: 294-298.

Festenstein, G.N., Lacey, J., Skinner, F.A., Jenkins, P.A. \& PEPYS, J. 1965. Self-heating of hay and grain in Dewar flasks and the development of farmer's lung antigens. J. Gen. Microbiol. 41: 389-407.

Gregory, P.H. \& LaCeY, M.E. 1963. Mycological examination of dust from mouldy hay associated with farmer's lung disease. J. Gen. Microbiol. 30: 75-88.

Husman, K., Vohlonen, I., Terho, E.O. \& Māntyjärvi, R.A. 1987. Precipitins against microbes in mouldy hay in the sera of farmers with farmer's lung or chronic bronchitis and of healthy farmers. Eur. J. Respir. Dis., Suppl. 152, 71: 122-127.

KotimaA, M., Kärenlampi, L., Terho, E.O., Husman, K. \& TUPI, K. 1984. Exposure to biological dusts in agrigulture. Part 2. At the end of the indoor feeding season for cattle. (In Finnish with Swedish and English summaries.) Publications of the Institute of Occupational Health No. 142., Institute of Occupational Health, Helsinki.

-, Mustonen, M. \& Husman, K. 1983. The effect of ADD-H preservative (ammonium propionate on the moulding of baled hay. J. Sci. Agric. Soc. Finland 55: $371-383$.

-, Tupi, K., Kărenlampi, L., Terho, E.O., Alanko, K. \& Husman, K. 1978. Exposure to biological dusts in agriculture. Part 1. At the beginning of the indoor feeding season for cattle. (In Finnish with Swedish and English summaries.) Publications of the Institute of Occupational Health No. 141., Institute of Occupational Health, Helsinki.

LACEY, J. 1971. The microbiology of moist barley storage in unsealed silos. Ann. appl. Biol. 69: 187-212.

Mulinge, S.K. \& Chesters, C.G.C. 1970. Ecology of fungi associated with moist stored barley grain. Ann. appl. Biol. 65: 277-284.

Mustonen, M., Husman, K., KotimaA, M. \& KärenlamPl, L. 1983. Molds and actinomycetes in grain: The concentrations of spores in work environments. (In Finnish with Swedish and English summaries.) Publications of the Institute of Occupational Health 1: $46-60,69-70,72-73$.

-, Kotimaa, M., Terho, E.O., Husman, K. \& Kären. LAMPI, L. 1984. The preservation methods of hay and silage and the mold exposure. (In Finnish with Swedish and English summaries.) Publications of the Institute of Occupational Health No. 206, Institute of Occupational Health, Helsinki.

PePYS, J. 1969. Hypersensitivity diseases of the lungs due to fungi and organic dusts. In: Monographs in Allergy, Vol. 4, P. Kallos, M. Hasek, T.M. Inderbitzin, P.A. Miescher and B.H. Waksman, eds. S. Karger, Basel.

Pether, J.V.S. \& Greatorex, F.B. 1976. Farmer's lung disease in Somerset. Br. J. Ind. Med. 33: 265-268.
Pirie, H.M., Dawson, C.O., Breeze, R.G., Wiseman, A. \& Hamilton, J. 1971. A Bovine disease similar to farmer's lung: Extrinsic allergic alveolitis. Vet. Rec. 88: $346-351$.

Russel, R.S. 1974. Mycology guidebook. University of Washington Press, Seattle.

Rylander, R. 1985. Organic dusts and lung reactions exposure characteristics and mechanisms for disease. Scand. J. Work Environ. Health 11: 199-206.

Solley, G.O. \& HyatT, R.E. 1980. Hypersensitivity pneumonitis induced by Penicillium species. J. Allergy Clin. Immunol. 65: 65-70.

Terho, E.O. 1978. Microbiological and serological studies on farmer's lung disease. Publications of the University of Kuopio, Medicine, Series Original Reports 1/1978. University of Kuopio, Kuopio.

—, Heinonen, O.P., Lammi, S. \& LaukKanen, V. 1987. Incidence of clinically confirmed farmer's lung in Finland and its relation to meteorological factors. Eur. J. Respir. Dis., Suppl. 152, 71: 47-63.

- \& LACEY, J. 1979. Microbiological and serological studies of farmer's lung in Finland. Clin. Allergy 9: $43-52$.

-, Lammi, S. \& Heinonen, O.P. 1980. Seasonal variation in the incidence of farmer's lung. Int. J. Epidemiol. 9: 219-220.

VaAranen, V., Vasama, M. \& Alho, J. 1985. Occupational diseases in 1984. (In Finnish.) Katsauksia 77. Institute of Occupational Health, Helsinki. 75 p.

-, Vasama, M. \& Alнo, J. 1986. Occupational diseases in 1985. (In Finnish.) Katsauksia 80. Institute of Occupational Health, Helsinki. 77 p.

-, VASAma, M. \& JolanKı, R. 1987. Occupational diseases in 1986. (In Finnish.) Katsauksia 88. Institute of Occupational Health, Helsinki. 80 p.

-, Vasama, M., Jolankı, R. \& TolkKanen, J. 1988. Occupational diseases in 1987. (In Finnish.) Katsauksia 92. Institute of Occupational Health, Helsinki. 74 p.

-, Vasama, M., Jolanki, R. \& TolkKanen, J. 1989. Occupational diseases in 1988. (In Finnish.) Katsauksia 101. Institute of Occupational Health, Helsinki. 74 p.

Vohlonen, I., Tupi, K., Terho, E.O. \& Husman, K. 1987. Prevalence and incidence of chronic bronchitis and farmer's lung with respect to the geographical location of the farm and to the work of farmers. Eur. J. Respir. Dis., Suppl. 152, 71: 37-46.

WARDROP, V.E., Blyth, W. \& GRANT, W.B. 1977. Farmer's lung in a group of Scottish dairy farms. $\mathrm{Br}$. J. Ind. Med. 34: 186-195.

Wiseman, A., Selman, I.E., Dawson, C.O., Breeze, R.G. \& PIRIE, H.M. 1973. Bovine farmer's lung: A clinical syndrome in a herd of cattle. Vet. Rec. 93: 410-417.

Ms received August, 8, 1989 


\section{SELOSTUS}

\section{Varastoidun heinän, viljan ja oljen käsittelystä aiheutuva itiöaltistus}

\section{Marjut Kotimaa}

Kuopion aluetyöterveyslaitos, PL 93, 70701 Kuopio

Työssả tutkittiin tavanomaisissa tilaolosuhteissa heinän, viljan ja kuivikkeina kăytettävien olkien käsittelyn aiheuttamaa homepölyaltistusta sisäruokintakauden lopulla. Ilmanäytteet mikrobien mäărittämiseksi kerättiin kuusivaihe-impaktoria (malli 10-800, Andersen Inc.) kāyttảen. Kuivikeolkien $(\mathrm{n}=5)$ aiheuttama homepölyaltistus $\left(3.7 \times 10^{6} \mathrm{cfu} / \mathrm{m}^{3}\right)$ oli merkittävästi suurempi kuin heinien $(\mathrm{n}=33)\left(0.6 \times 10^{6} \mathrm{cfu} / \mathrm{m}^{3}\right)$ tai rehuviljan $(\mathrm{u}=2)\left(0.2 \times 10^{6}\right.$ $\left.\mathrm{cfu} / \mathrm{m}^{3}\right)$. Spontaania lämpenemistä osoittavien termotoleranttien sienten ja termofiilisten aktinomykeettien esiintyminen oli ominaista oljille. Heinăstă irronneiden termotoleranttien sienten itiöiden mäără oli vain noin $10 \%$ ja viljasta irronneiden alle $1 \%$ olkeen verrattuna, termofiilisten aktinomykeettien itiöitä irtosi heinästă vastaavasti noin $5 \%$ ja viljasta $0.4 \%$ oljesta irronneisiin mäăriin verrattuna.

Kuivikeolkien aiheuttaman itiöaltistuksen valtalaji oli Thermoactinomyces vulgaris, heinän ja viljan puolestaan Aspergillus umbrosus. Kaikissa materiaaleissa esiintyi run- saasti erilaisia varastosieninä tunnettuja Aspergillus- ja Penicillium -suvun lajeja (mm. Aspergillus (A.) fumigatus, A. ochraceus, A. flavus, A. repens, $A$. versicolor, Penicillium ( $P$.) expansum, $P$. piceum, $P$. citrinum, $P$. brevicompactum, $P$. echinulatum, $P$. verrucosum var. cyclopium). Heinissä esiintyi tyypillisesti myös ns. peltosienină pidettyjä Cladosporium-suvun lajeja, kuten $\mathrm{Cla}$ dosporium (C.) herbarum, C. cladosporioides ja C. macrocarpum. Saadut tulokset osoittavat, että rehujen ja kuivikkeiden käsittely maataloudessa altistaa perinteisesti homepölykeuhkon aiheuttajina tunnettujen mikrobien lisăksi mm. monille Penicillium-suvun homeille. Kuivikeolkien mikrobiologinen laatu oli huono heinään ja viljaan verrattuna, heinăn laatuvaihtelu oli suurta. Tulokset tukevat sită kăsitystă, ettă varastokuivureita tarvitaan sekả heinăn ettă kuivikeolkien kuivaamiseen, jotta näiden materiaalien homehtumisriski ja altistumisen aiheuttamat terveysriskit voitaisiin minimoida. 